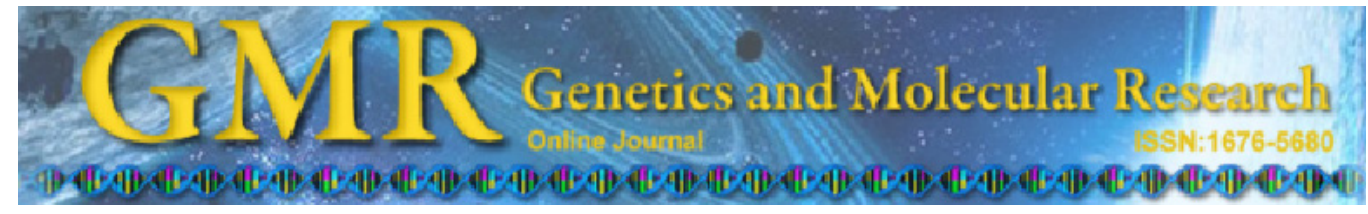

\title{
Luteinizing hormone receptor splicing variants in bovine Leydig cells
}

\author{
T.H. Ma ${ }^{1 *}$, Q.H. Xiong ${ }^{1 *}$, B. Yuan ${ }^{1,2}$, H. Jiang ${ }^{1}$, Y. Gao ${ }^{1,2}$, J.B. Xu ${ }^{1}$, \\ S.Y. Liu', Y. Ding', G.L. Zhang ${ }^{3}$, Y.M. Zhao ${ }^{3}$ and J.B. Zhang ${ }^{1,2}$ \\ ${ }^{1}$ College of Animal Science and Veterinary Medicine, Jilin University, \\ Changchun, China \\ ${ }^{2}$ Laboratory Animal Center, Jilin University, Changchun, China \\ ${ }^{3}$ Jilin Academy of Agricultural Sciences, Changchun, China \\ *These authors contributed equally to this study. \\ Corresponding authors: J.B. Zhang / Y. Ding \\ E-mail: zjb515@163.com / dingyu03@163.com
}

Genet. Mol. Res. 11 (2): 1721-1730 (2012)

Received August 1, 2011

Accepted March 15, 2012

Published June 29, 2012

DOI http://dx.doi.org/10.4238/2012.June.29.4

\begin{abstract}
The luteinizing hormone receptor (LHR) plays a key role in testosterone production through its interaction with the gonadotropins, LH and chorionic gonadotropin. We examined the $L H R$ splicing pattern in bovine Leydig cells; LH-induced expression of eight cloned splicing variants was detected by real-time PCR. Luteinizing hormone applied to cultured Leydig cells resulted in expression of full-length LHR and the $\mathrm{A}$ and $\mathrm{B}$ isoforms, as well as secretion of testosterone, which first increased, then declined, and then increased further, with increased LH levels. The secretion of testosterone progressively increased with increasing LH, but the expression levels of LHR (FL, A, and B) did not increase correspondingly. We conclude that the LHR splicing pattern is complex in bovine Leydig cells, and that expression of full-length LHR and isoforms $\mathrm{A}$ and $\mathrm{B}$ changes when induced with $\mathrm{LH}$.
\end{abstract}

Key words: Bovine; Leydig cells; LHR; Splicing variants 


\section{INTRODUCTION}

The luteinizing hormone receptor (LHR) is a member of the G-protein coupled receptor superfamily and consists of an extracellular domain, seven transmembrane domains connected by alternating intracellular and extracellular loops, and an intracellular carboxyl (C)-terminal tail (Ascoli et al., 2002). The LHR has a pivotal role in testicular development and function (Zhang et al., 2001). Upon binding to luteinizing hormone (LH) or its placental counterpart, chorionic gonadotropin (CG), the receptor stimulates adenylyl cyclase activity, cyclic adenosine 3', 5'-monophosphate production (Davis et al., 1996), and consequently, activation of the Leydig cells and testosterone production. Inactivating mutations of $L H R$ can make Leydig cells resistant to the actions of CG and LH, causing hypoplasia of the Leydig cells and decreased production of testosterone. This gives rise to hypogonadism or male pseudohermaphroditism, called Leydig cell hypoplasia or Leydig cell agenesis (Wu and Chan, 1999). Under normal physiological conditions, testosterone is almost exclusively ( $>95 \%)$ of testicular origin (Wilson et al., 1981). Thus, the quality and quantity of LHR are important factors affecting the sensitivity to its ligand (Kawate, 2004).

The $L H R$ gene is subject to alternative splicing, giving rise to several mRNA variants. Indeed, transcripts encoding alternatively spliced variants of the LHR have been detected in rat (Aatsinki et al., 1992), sheep (Bacich et al., 1994), horse ovary (Saint-Dizier et al., 2003), human corpus luteum (Nishimori et al., 1995), pig (Loosfelt et al., 1989), marmoset monkey (Michel et al., 2007), turkey (You et al., 2000), and cattle follicles (Robert et al., 2003). Although binding and functional properties of $L H R$ splice variants have not been fully elucidated, it has been shown that the variants with a partial deletion of exon 11 are translated into protein, but not translocated to the cell membrane (Bacich et al., 1999; Kawate, 2004). In rats, deletion of the first 266 bp of exon 11 causes a frame shift in the reading frame and creates a truncated translation product. Importantly, coexpression of the variant with the fulllength $L H R$ resulted in a reduction in the number of cell surface receptors (Apaja et al., 2006). A deletion of exon 10 of the human LHR resulted in impaired activation by LH, in contrast with hCG (Müller et al., 2003), for which the variant lacking exon 9 is capable of forming receptor complexes with the full-length LHR (Nakamura et al., 2004). The functional role of this alternative splicing remains to be fully characterized. To date, it is not yet known if any alternatively spliced mRNAs are translated in vivo, in any species.

The alternative splicing mechanisms that give rise to the receptor variants may be subject to metabolic regulation or altered in pathophysiological states, leading to modulation of tissue expression of the receptor variants and resulting in potential changes in LH action (Minegishi et al., 1997). The objective of this study is to characterize the LHR splicing pattern in bovine Leydig cells and detect expression of some variants as affected by LH induction.

\section{MATERIAL AND METHODS}

\section{Isolation of primary cells}

Testes were obtained from mature Simmental cattle from a local abattoir. They were then transported to the laboratory in ice-cold phosphate-buffered saline (PBS) containing penicillin $(100 \mathrm{IU} / \mathrm{mL})$ and streptomycin $(100 \mathrm{IU} / \mathrm{mL})$. 
Leydig cells were isolated from bovine testes by collagenase $\alpha$ dispersion and Percoll density gradient centrifugation as described earlier (Shiraishi and Ascoli, 2007), with slight modifications. Leydig cells were dissociated from the seminiferous tubules with $0.25 \mathrm{mg} / \mathrm{mL}$ collagenase (Invitrogen, USA) in medium 199 for $30 \mathrm{~min}$ at $37^{\circ} \mathrm{C}$ by shaking. The digested tissue was successively filtered through a 200 - and a $76-\mu \mathrm{m}$ pore-size nylon mesh. The filtrate was centrifuged at $300 \mathrm{~g}$ for $8 \mathrm{~min}$ at room temperature, and the pellet was washed once by centrifugation with Hank's balanced salt solution without $\mathrm{Ca}^{2+}$ or $\mathrm{Mg}^{2+}$ (D-Hank's) containing $0.1 \%(\mathrm{w} / \mathrm{v})$ BSA. To obtain purified Leydig cells, $2 \mathrm{~mL}$ of the crude cell suspension was loaded on top of a discontinuous Percoll gradient (5, 30, 58, and 90\% Percoll) and centrifuged at $800 \mathrm{~g}$ for $20 \mathrm{~min}$. Cell viability was estimated with $0.4 \%$ Trypan blue stain and cell purity

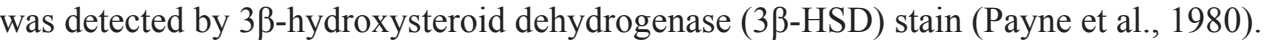

\section{Cell culture}

The purified Leydig cells were resuspended in DMEM/F12 (11330-032; Invitrogen), $10 \%$ fetal bovine serum (HyClone, USA), $100 \mathrm{IU} / \mathrm{mL}$ penicillin, and $100 \mathrm{IU} / \mathrm{mL}$ streptomycin. Pooled cells were seeded into 24-well plates (Corning, USA) at a density of $1 \times 10^{6}$ in 1 $\mathrm{mL}$ medium (Svechnikov et al., 2001). Cultures were maintained at $37^{\circ} \mathrm{C}$ in $5 \% \mathrm{CO}_{2}$ for $24 \mathrm{~h}$. To measure the effect of LH on testosterone secretion, cells were incubated with serum-free DMEM/F12 containing graded doses of LH (Serono Laboratories; $0,1 \times 10^{-5}, 1 \times 10^{-4}, 1 \mathrm{x}$ $10^{-3}, 1 \times 10^{-2}, 1 \times 10^{-1}, 1 \mathrm{IU} / \mathrm{mL}$ ) for $24 \mathrm{~h}$ of culture. At the end of culturing time, medium was collected and measured for testosterone levels using an in-house RIA (Zamecnik et al., 1977; Chandolia et al., 2006), and cells were collected for RNA extraction. Experiments were performed with three independent cultures.

\section{RNA isolation, RT-PCR}

Total RNA of Leydig cells was isolated using the Trizol reagent following the manufacturer protocol and including treatment with DNase I (Promega, USA). The cells from identical wells were combined prior to RNA extraction. The RNA was quantified spectrophotometrically, and stored at $-80^{\circ} \mathrm{C}$ until further analysis.

In order to examine alternatively spliced mRNA for bovine LHR in the Leydig cells, primers were designed based on the cDNA sequence of bovine LHR submitted to the GenBank by Lussier (accession No. U20504). Due to the high GC content of the 5'-untranslated region of $L H R$ and exon 1, the forward primer (5'-CTCAGCCGACTATCACTCAC-3') was located in the junction of exon 1 and exon 2; the reverse primer (5'-TGACACCCACAAGAGGCAAC3') was located in the middle of exon 11 (Figure 1).

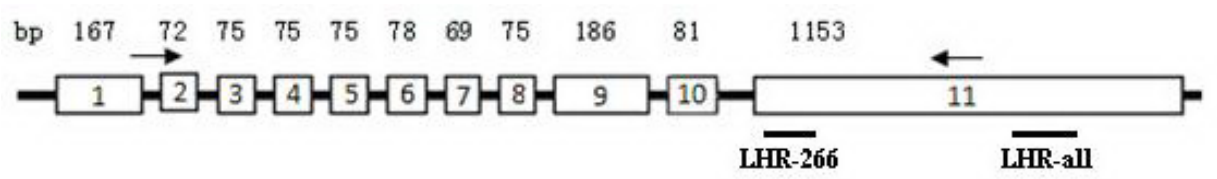

Figure 1. PCR primers for amplification of luteinizing hormone receptor (LHR) splicing variants. Exons are indicated by numbered boxes; base pair $(\mathrm{bp})$ length is indicated above each exon. The arrows indicate the priming sites used for RT-PCR amplification of LHR isoforms. LHR-266 represents the location of primers for real-time PCR used for quantification of full-length $L H R$ and isoforms A and B. 
RNA was used as a template for cDNA synthesis using the PrimeScript ${ }^{\mathrm{TM}}$ 1st-Strand cDNA Synthesis Kit (TaKaRa, Japan) according to manufacturer instructions. After the reverse transcription reaction, PCR amplification was performed using Taq DNA Polymerase (TIANGEN, Beijing, China). The reaction mixture included $1 \mu \mathrm{L}$ cDNA, $1 \mathrm{U}$ Taq DNA polymerase, $1 \mathrm{X}$ Taq reaction buffer, $0.25 \mathrm{mM}$ dNTPs, and $5 \mu \mathrm{M}$ each primer, in a total volume of $20 \mu \mathrm{L}$. Samples were denatured for $4 \mathrm{~min}$ at $95^{\circ} \mathrm{C}$, followed by 35 cycles of $40 \mathrm{~s}$ at $94^{\circ} \mathrm{C}, 40 \mathrm{~s}$ at $60^{\circ} \mathrm{C}, 90 \mathrm{~s}$ at $72^{\circ} \mathrm{C}$, and a final elongation step of $72^{\circ} \mathrm{C}$ for $10 \mathrm{~min}$. After PCR, the amplicons were electrophoresed on $2 \%$ agarose gels and visualized by UV fluorescence after ethidium bromide staining. To identify the different $L H R$ splice variants, the amplicons were ligated into the pMD18-T vector (TaKaRa) and sequenced using the dideoxynucleotide termination method (Sanger et al., 1977).

\section{Real-time quantitative PCR}

Real-time amplification was performed in triplicate $25 \mu \mathrm{L}$ reactions using SYBR Green Real-Time PCR Master Mix (TOYOBO, Japan) following the manufacturer instructions and using the Mastercycler ep Realplex instrument (Eppendorf, Germany). Primers were designed according to the sequence characteristics of $L H R$ splicing isoforms; the histone $H 2 a$ gene was used as an endogenous control as previously described (Robert et al., 2002; Buratini et al., 2005). Primers used were as follows: LHR-266 forward, 5'-TTCTGCTTACCCAAGAC ACTC-3'; LHR-266 reverse, 5'-TAATCAGCCAAATCAGGACTC-3'; H2a forward, 5'-GTCG TGGCAAGCAAGGAG-3', and H2a reverse, 5'-GATCTCGGCCGTTAGGTACTC-3'. The LHR-266 primers had a melting temperature of $50^{\circ} \mathrm{C}$ and amplified a fragment of $106 \mathrm{bp}$. The $\mathrm{H} 2 \mathrm{a}$ primers had a melting temperature of $55^{\circ} \mathrm{C}$ and amplified a fragment of $182 \mathrm{bp}$. Relative gene expression analysis was performed according to the $2^{-\Delta \Delta C t}$ method (Livak and Schmittgen, 2001).

\section{Statistical analysis}

Statistical analyses were carried out using SPSS (SPSS, Inc., version 13.0, Chicago, IL, USA). Statistical analyses of all data from three replicates were carried out by one-way ANOVA followed by a Duncan multiple-range test. Differences were considered to be significant at $\mathrm{P}<0.05$ (Dickinson et al., 2008).

\section{RESULTS}

\section{Different splicing variants of bovine $L H R$ in Leydig cells}

The primer pair used here was different from any primer used previously in studies of other species. It was designed to amplify a 1366-bp fragment that comprises the region of alternative splicing in other species (Aatsinki et al., 1992; Bacich et al., 1994; Reinholz et al., 2000), and is thus likely to include all variants of the LH receptor. When cDNA from bovine Leydig cells was analyzed by RT-PCR using this primer pair, at least 5 bands were observed, suggesting the presence of splice variants (Figure 2). To identify the different variants, the PCR products were directly ligated into the pMD18-T vector (Michel et al., 2007). From over 400 clones, more than 50 variants with different insert sizes were sequenced and aligned with 
the published bovine LHR cDNA sequence using NCBI Blast. We identified eight different isoforms, not including the full-length form; these 8 variants were named $\mathrm{A}$ through $\mathrm{H}$ forms, from largest to smallest in size (Figure 3). We could not determine a perfect match between the 9 splice variants and the 5 bands on the agarose gel, due to some variants being of comparable size or exhibiting extremely low expression. Isoform FL is the full-length receptor, which is the wild-type receptor in bovine Leydig cells. Although exon deletion was observed in isoforms $\mathrm{A}$ and $\mathrm{B}$, no frame shift was observed and exon 11 was complete. Isoforms $\mathrm{C}, \mathrm{D}, \mathrm{E}$, $\mathrm{G}$, and $\mathrm{H}$ were spliced from the 3 '-end of exon 10 into the first $266 \mathrm{bp}$ of exon 11, commonly generating a frame shift that caused a unique 46-amino acid sequence and a premature stop codon. Isoform $\mathrm{F}$ was missing exon 10 and the first $428 \mathrm{bp}$ of exon 11, leading to premature termination and a unique 89-amino acid sequence (Figure 4).

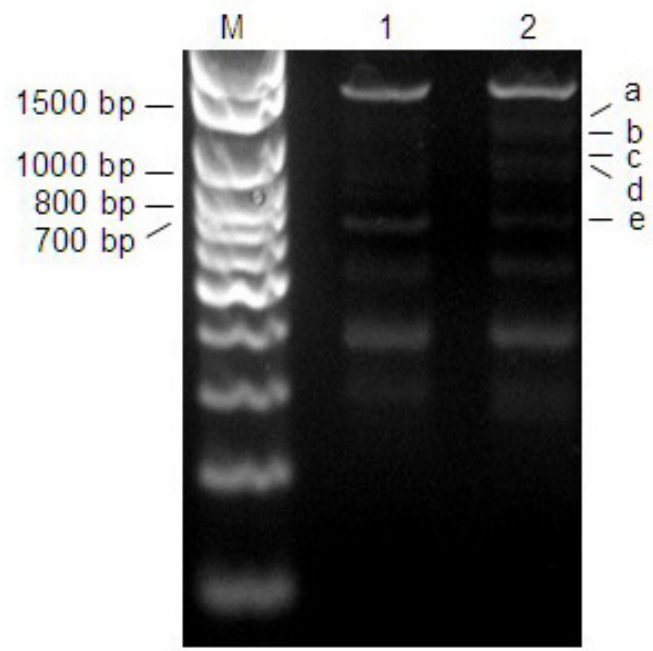

Figure 2. Agarose gel electrophoresis of $L H R$ PCR products. Lane $M=$ Indicates the marker; lanes 1 and $2=$ are two replicates of the PCR amplification. a, b, c, d, and e indicate the variants of $L H R$. Other bands are unspecific amplicons.

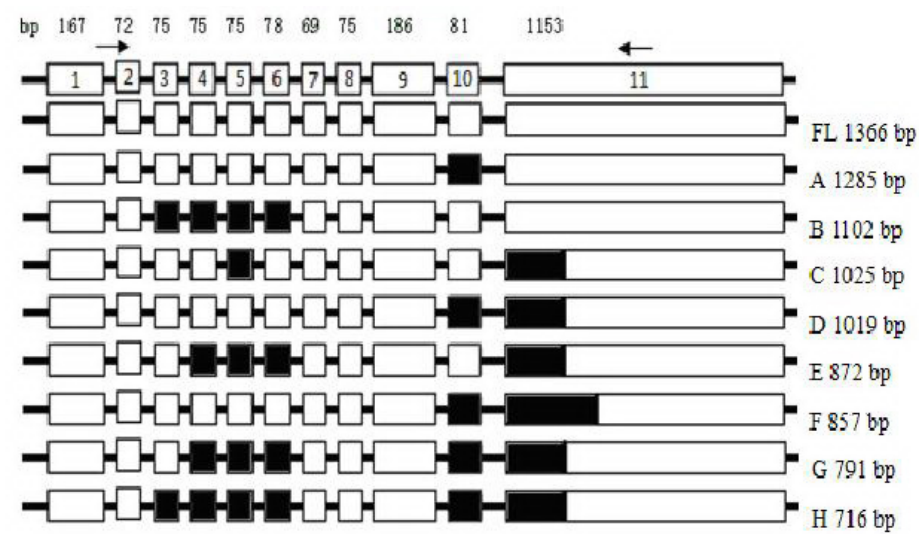

Figure 3. Schematic diagram of the $L H R$ splicing variants, indicating exons. Black boxes correspond to deleted exons. The arrows indicate the priming sites. The 5'-part (266 bp) of exon 11 was deleted in five splice variants $(\mathrm{C}$, $\mathrm{D}, \mathrm{E}, \mathrm{G}$, and $\mathrm{H}$ ), and the first $428 \mathrm{bp}$ of exon 11 were deleted in $\mathrm{F}$. $\mathrm{FL}=$ full-length receptor. 


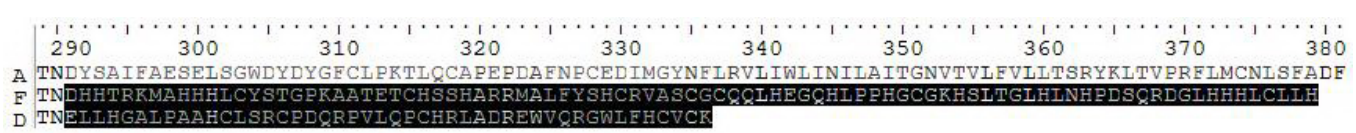

Figure 4. The amino acid sequences of three bovine luteinizing hormone receptors (LHRs). The black area is the unique carboxyl (C)-terminal tail resulting from a frame shift.

\section{Effects of LH induction on testosterone secretion and $L H R$ expression in Leydig cells}

As a general trend, the secretion of testosterone increased along with an increase in the LH concentration from 0 to $1 \times 10^{-4} \mathrm{IU} / \mathrm{mL}$. More specifically, to an $\mathrm{LH}$ concentration of $1 \mathrm{x}$ $10^{-4} \mathrm{IU} / \mathrm{mL}$, the secretion of testosterone increased to a level that was significantly higher than that of control cells $(\mathrm{P}<0.05)$. After that point, as the LH concentration continued to increase, testosterone concentration declined briefly, reaching a nadir at the LH concentration of $1 \mathrm{x}$ $10^{-3} \mathrm{IU} / \mathrm{mL}$. Then, the testosterone level began to progressively increase, reaching a secondary peak at $\mathrm{LH}$ concentrations of $1 \times 10^{-1}$ and $1 \mathrm{IU} / \mathrm{mL}$, where the secretion of testosterone was again significantly higher than that of control cells $(\mathrm{P}<0.01)$ (Figure 5).

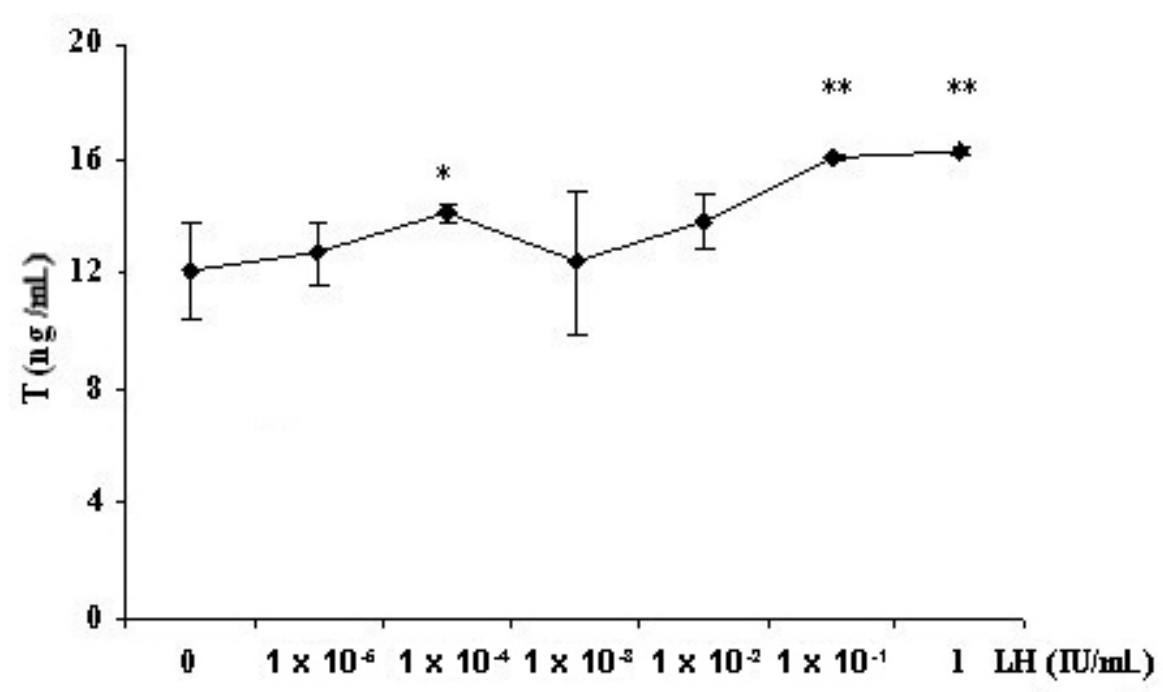

Figure 5. Effects of luteinizing hormone (LH) induction on testosterone production in cultured Leydig cells. Cells were induced with serial dilutions of $\mathrm{LH}$ for $24 \mathrm{~h}$. Results are means $\pm \mathrm{SEM}(\mathrm{N}=3)$ concentrations of testosterone $(\mathrm{T}, \mathrm{ng} / \mathrm{mL})$ in the culture media compared with control. $* \mathrm{P}<0.05, * * \mathrm{P}<0.01$.

Although numerous alternative LHR mRNA splice variants have been examined in bovine testes, quantification of the relative expression level of each variant has been harder to achieve. Based on the features of the variants, we designed one specific primer pair, located in the first 266 bp of exon 11, to quantify the total expression of full-length LHR and the A and B isoforms, which all contain a complete exon 11 (Figure 1 and Figure 3). With the stimulation of $\mathrm{LH}$, the expression of these 3 isoforms initially increased, followed by a dramatic decrease at an $\mathrm{LH}$ concentration of $1 \times 10^{-3} \mathrm{IU} / \mathrm{mL}$ (Figure 6). However, as LH increased from $1 \times 10^{-3}$ 
$\mathrm{IU} / \mathrm{mL}$ to $1 \times 10^{-1} \mathrm{IU} / \mathrm{mL}$, the expression of those variants was relatively stable (Figure 6) while the testosterone secretion under the same rising LH levels increased significantly $(\mathrm{P}<$ 0.01) (Figure 5).

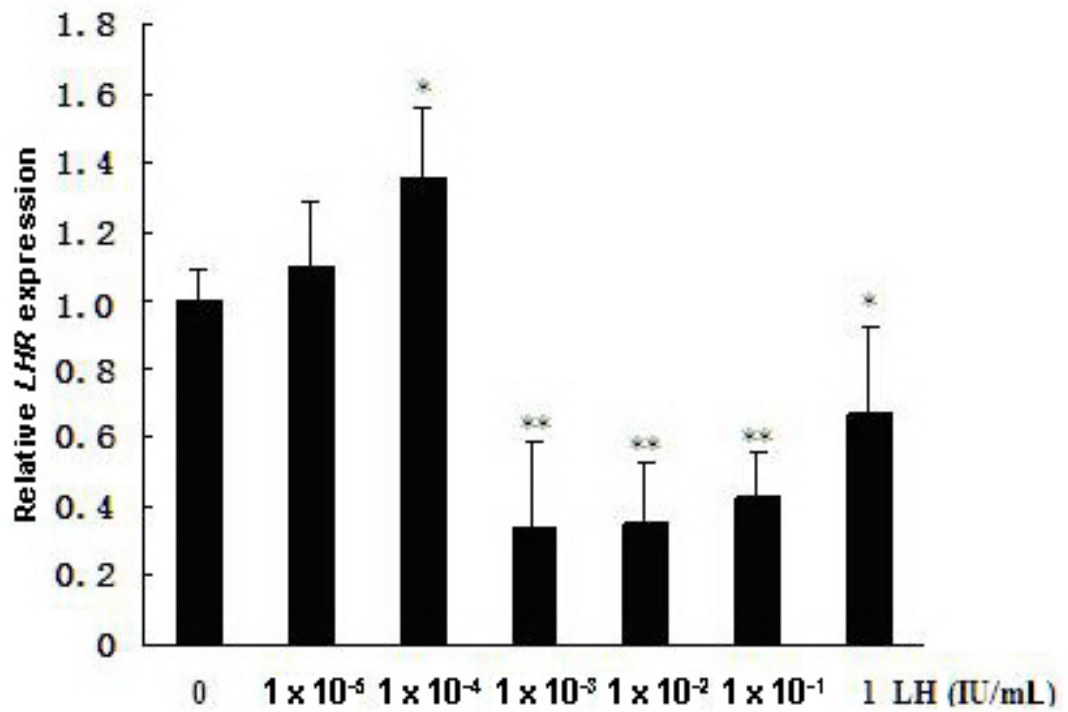

Figure 6. The expression of luteinizing hormone receptor (LHR) splicing variants in luteinizing hormone (LH)induced bovine Leydig cells. The expression of functional receptors in LH-induced bovine Leydig cells, including full-length receptor, and A and B forms, were detected by real-time PCR. Results represent the means \pm SEM (N $=3) . * \mathrm{P}<0.05, * * \mathrm{P}<0.01$.

\section{DISCUSSION}

Throughout the evolutionary process, several single-copy genes have been duplicated, often resulting in modified sequences and functions. RNA splicing is an essential, precisely regulated, post-transcriptional process that occurs prior to mRNA translation (Michel et al., 2007). Alternative splicing is a widespread device for gene regulation and for generating isoform diversity (Smith et al., 1989). Previous studies have demonstrated that, in addition to mRNA of the LH holoreceptor, splice variants of LHR mRNA exist in several species. These variants are of different sizes, consistent with deletions of complete or partial exons within the genomic structure. In this paper, we described the presence of alternative LHR splicing in bovine Leydig cells and we quantified the expression level of the full-length receptor and variants $\mathrm{A}$ and $\mathrm{B}$ as it correlated with $\mathrm{LH}$ induction.

The splicing pattern is complex in bovine Leydig cells. This study has shown that two thirds of the variants were lacking part of exon 11, along with other exons. Interestingly, we detected an isoform (F) that had not been found previously. If the splice variant is translated into protein, the LHR protein encoded by the F splice variant is shorter than the full-length form, not only because exon 10 is spliced out, but also because the splicing is out of frame, producing a premature stop codon and an alternative carboxyl-terminus. The proteins encoded by the $\mathrm{C}, \mathrm{D}, \mathrm{E}, \mathrm{G}$, and $\mathrm{H}$ forms are similar, but with a different carboxyl-terminus than en- 
coded by F (Figure 4). Furthermore, the A, D, F, G, and H forms have a common deletion of exon 10. Exon 10 comprises $81 \mathrm{bp}$, encoding 27 amino acids, in the hinge region of the extracellular domain (Gromoll et al., 2000). According to present knowledge, exon 10 of the LHR is not crucial for signal transduction by hCG (Zhang et al., 1998). However, Müller et al. (2003) confirmed that while deletion of exon 10 does not affect hCG action, LH action is impaired. This resulted in maternal hCG interaction with the deleted LHR in the embryonal phase that is decisive for male development, with impaired LH action at puberty, and failure of sexual maturation.

The variants with a partial deletion of exon 11 encode putative proteins that have no transmembrane or intracellular domains. Previous studies have shown that the variants with a partial deletion of exon 11 are translated into protein, but are not translocated to the cell membrane and instead become intracellularly trapped (Kawate, 2004). Thus, if these mRNAs are translated they are unable to bind LH and cannot activate adenylyl cyclase. In this study, we only designed one pair of primers to quantify the expressions of full-length LHR and the A and $B$ isoforms, which each have a complete exon 11. Previous studies have shown that continuous exposure to high concentrations of LH/hCG attenuates the cellular response (Lu et al., 1993; Chuzel et al., 1995). Our results demonstrated that the secretion of testosterone increased and reached a maximum at the concentration of $1 \times 10^{-4} \mathrm{IU} / \mathrm{mL}$. The Leydig cells seemed to not be sensitive to further increases of LH, and the secretion of testosterone dropped at the LH concentration of $1 \times 10^{-3} \mathrm{IU} / \mathrm{mL}$. Interestingly, the changes in expression of full-length LHR, $\mathrm{A}$, and $\mathrm{B}$ at different LH levels were consistent with the changes in testosterone secretion with the same LH changes. These results suggest that the full-length LHR and the A and B isoforms may play a leading role in the response to LH. The mechanism by which the expression of these receptors decreases is still unknown; it might relate to decreased transcriptional activity and/or destabilization of receptor mRNA (Kishi et al., 1997). Recently, studies have indicated that alternative processing of receptor pre-mRNA play a regulatory role in the expression of functional LH/CG receptors during down- and up-regulation (Lakkakorpi et al., 1993) and differential mRNA splicing might be a mechanism for desensitization (Minegishi et al., 1997). We have identified 8 splicing variants of LHR; most of them have a partial deletion of exon 11 that leads to a frame shift and a premature stop codon. If these variants are translated and subsequently trapped intracellularly, their function still needs to be studied. When induced with an LH concentration in the range of $1 \times 10^{-3}$ to $1 \mathrm{IU} / \mathrm{mL}$, the testosterone capacity of Leydig cells increased correspondingly, but the expression of three types of splicing variants (fulllength, A, and B) remained stable. This suggests that Leydig cells reach a point of maximum efficiency at where a further increase in receptor expression no longer stimulates additional secretion of testosterone.

In summary, here we describe the bovine LHR splicing pattern in bovine Leydig cells and the gene expression in Leydig cells as it corresponds to varying levels of LH induction. We conclude that the splicing variants full-length, A and B seem to play an important role in testosterone secretion and a small proportion of these receptors are sufficient to evoke full biological response.

\section{ACKNOWLEDGMENTS}

Research supported by the National Natural Science Foundation (Grant \#30972100), 
the Earmarked Fund for Modern Agro-Industry Technology Research System (Grant \#CARS38), and the Technology Development Program of Jilin Province (Grant \#20090237).

\section{REFERENCES}

Aatsinki JT, Pietila EM, Lakkakorpi JT and Rajaniemi HJ (1992). Expression of the LH/CG receptor gene in rat ovarian tissue is regulated by an extensive alternative splicing of the primary transcript. Mol. Cell Endocrinol. 84: 127-135.

Apaja PM, Tuusa JT, Pietila EM, Rajaniemi HJ, et al. (2006). Luteinizing hormone receptor ectodomain splice variant misroutes the full-length receptor into a subcompartment of the endoplasmic reticulum. Mol. Biol. Cell 17: 22432255.

Ascoli M, Fanelli F and Segaloff DL (2002). The lutropin/choriogonadotropin receptor, a 2002 perspective. Endocr. Rev. 23: 141-174.

Bacich DJ, Rohan RM, Norman RJ and Rodgers RJ (1994). Characterization and relative abundance of alternatively spliced luteinizing hormone receptor messenger ribonucleic acid in the ovine ovary. Endocrinology 135: 735-744.

Bacich DJ, Earl CR, O'Keefe DS, Norman RJ, et al. (1999). Characterization of the translated products of the alternatively spliced luteinizing hormone receptor in the ovine ovary throughout the oestrous cycle. Mol. Cell Endocrinol. 147: $113-124$

Buratini J Jr, Teixeira AB, Costa IB, Glapinski VF, et al. (2005). Expression of fibroblast growth factor-8 and regulation of cognate receptors, fibroblast growth factor receptor-3c and -4, in bovine antral follicles. Reproduction 130: 343-350.

Chandolia RK, Luetjens CM, Wistuba J, Yeung CH, et al. (2006). Changes in endocrine profile and reproductive organs during puberty in the male marmoset monkey (Callithrix jacchus). Reproduction 132: 355-363.

Chuzel F, Schteingart H, Vigier M, Avallet O, et al. (1995). Transcription and post-transcriptional regulation of luteotropin/ chorionic gonadotropin receptor by the agonist in Leydig cells. Eur. J. Biochem. 229: 316-325.

Davis JS, May JV and Keel BA (1996). Mechanisms of hormone and growth factor action in the bovine corpus luteum. Theriogenology 45: 1351-1380.

Dickinson RE, Myers M and Duncan WC (2008). Novel regulated expression of the SLIT/ROBO pathway in the ovary: possible role during luteolysis in women. Endocrinology 149: 5024-5034.

Gromoll J, Eiholzer U, Nieschlag E and Simoni M (2000). Male hypogonadism caused by homozygous deletion of exon 10 of the luteinizing hormone (LH) receptor: differential action of human chorionic gonadotropin and LH. J. Clin. Endocrinol. Metab. 85: 2281-2286.

Kawate N (2004). Studies on the regulation of expression of luteinizing hormone receptor in the ovary and the mechanism of follicular cyst formation in ruminants. J. Reprod. Dev. 50: 1-8.

Kishi H, Minegishi T, Tano M, Abe Y, et al. (1997). Down-regulation of LH/hCG receptor in rat cultured granulosa cells. FEBS Lett. 402: 198-202.

Lakkakorpi JT, Pietila EM, Aatsinki JT and Rajaniemi HJ (1993). Human chorionic gonadotrophin (CG)-induced downregulation of the rat luteal $\mathrm{LH} / \mathrm{CG}$ receptor results in part from the down-regulation of its synthesis, involving increased alternative processing of the primary transcript. J. Mol. Endocrinol. 10: 153-162.

Livak KJ and Schmittgen TD (2001). Analysis of relative gene expression data using real-time quantitative PCR and the 2(-Delta Delta C(T)) Method. Methods 25: 402-408.

Loosfelt H, Misrahi M, Atger M, Salesse R, et al. (1989). Cloning and sequencing of porcine LH-hCG receptor cDNA: variants lacking transmembrane domain. Science 245: 525-528.

Lu DL, Peegel H, Mosier SM and Menon KM (1993). Loss of lutropin/human choriogonadotropin receptor messenger ribonucleic acid during ligand-induced down-regulation occurs post transcriptionally. Endocrinology 132: 235-240.

Michel C, Gromoll J, Chandolia R, Luetjens CM, et al. (2007). LHR splicing variants and gene expression in the marmoset monkey. Mol. Cell Endocrinol. 279: 9-15.

Minegishi T, Tano M, Abe Y, Nakamura K, et al. (1997). Expression of luteinizing hormone/human chorionic gonadotrophin (LH/HCG) receptor mRNA in the human ovary. Mol. Hum. Reprod. 3: 101-107.

Müller T, Gromoll J and Simoni M (2003). Absence of exon 10 of the human luteinizing hormone (LH) receptor impairs LH, but not human chorionic gonadotropin action. J. Clin. Endocrinol. Metab. 88: 2242-2249.

Nakamura K, Yamashita S, Omori Y and Minegishi T (2004). A splice variant of the human luteinizing hormone (LH) receptor modulates the expression of wild-type human LH receptor. Mol. Endocrinol. 18: 1461-1470.

Nishimori K, Dunkel L, Hsueh AJ, Yamoto M, et al. (1995). Expression of luteinizing hormone and chorionic gonadotropin receptor messenger ribonucleic acid in human corpora lutea during menstrual cycle and pregnancy. $J$. Clin. Endocrinol. Metab. 80: 1444-1448.

Payne AH, Downing JR and Wong KL (1980). Luteinizing hormone receptors and testosterone synthesis in two distinct 
populations of Leydig cells. Endocrinology 106: 1424-1429.

Reinholz MM, Zschunke MA and Roche PC (2000). Loss of alternately spliced messenger RNA of the luteinizing hormone receptor and stability of the follicle-stimulating hormone receptor messenger RNA in granulosa cell tumors of the human ovary. Gynecol. Oncol. 79: 264-271.

Robert C, McGraw S, Massicotte L, Pravetoni M, et al. (2002). Quantification of housekeeping transcript levels during the development of bovine preimplantation embryos. Biol. Reprod. 67: 1465-1472.

Robert C, Gagne D, Lussier JG, Bousquet D, et al. (2003). Presence of LH receptor mRNA in granulosa cells as a potential marker of oocyte developmental competence and characterization of the bovine splicing isoforms. Reproduction 125: 437-446.

Saint-Dizier M, Chopineau M, Dupont J, Daels PF, et al. (2003). Expression and binding activity of luteinizing hormone/ chorionic gonadotropin receptors in the primary corpus luteum during early pregnancy in the mare. Biol. Reprod. 69: 1743-1749.

Sanger F, Nicklen S and Coulson AR (1977). DNA sequencing with chain-terminating inhibitors. Proc. Natl. Acad. Sci. U. S. A. 74: 5463-5467.

Shiraishi K and Ascoli M (2007). Lutropin/choriogonadotropin stimulate the proliferation of primary cultures of rat Leydig cells through a pathway that involves activation of the extracellularly regulated kinase 1/2 cascade. Endocrinology 148: 3214-3225.

Smith CW, Patton JG and Nadal-Ginard B (1989). Alternative splicing in the control of gene expression. Annu. Rev. Genet. 23: 527-577.

Svechnikov KV, Sultana T and Soder O (2001). Age-dependent stimulation of Leydig cell steroidogenesis by interleukin-1 isoforms. Mol. Cell Endocrinol. 182: 193-201.

Wilson JD, Griffin JE, George FW and Leshin M (1981). The role of gonadal steroids in sexual differentiation. Recent Prog. Horm. Res. 37: 1-39.

Wu SM and Chan WY (1999). Male pseudohermaphroditism due to inactivating luteinizing hormone receptor mutations. Arch. Med. Res. 30: 495-500.

You S, Kim H, Hsu CC, El Halawani ME, et al. (2000). Three different turkey luteinizing hormone receptor (tLH-R) isoforms I: characterization of alternatively spliced tLH-R isoforms and their regulated expression in diverse tissues. Biol. Reprod. 62: 108-116.

Zamecnik J, Barbe G, Moger WH and Armstrong DT (1977). Radioimmunoassays for androsterone, 5alpha-androstane$3 \alpha, 17 \beta$-diol and $5 \alpha$-androstane-3 $\beta, 17 \beta$-diol. Steroids 30: 679-689.

Zhang FP, Kero J and Huhtaniemi I (1998). The unique exon 10 of the human luteinizing hormone receptor is necessary for expression of the receptor protein at the plasma membrane in the human luteinizing hormone receptor, but deleterious when inserted into the human follicle-stimulating hormone receptor. Mol. Cell Endocrinol. 142: 165-174.

Zhang FP, Poutanen M, Wilbertz J and Huhtaniemi I (2001). Normal prenatal but arrested postnatal sexual development of luteinizing hormone receptor knockout (LuRKO) mice. Mol. Endocrinol. 15: 172-183. 